\title{
Effects of saline stress and temperature on germination and seed vigor of Luffa
} operculata L. Cogn.

\author{
Paulo Costa Araújo ${ }^{1}$, Paulo Alexandre Fernandes Rodrigues de Melo ${ }^{2}$, Edna Ursulino Alves ${ }^{1}$, Antônio \\ Pereira dos Anjos Neto ${ }^{1}$, Aderson Costa Araujo Neto ${ }^{1}$, José Ribamar Gusmão de Araújo ${ }^{2}$, Janaina Marques \\ Mondego $^{2}$, Aline Priscilla Gomes da Silva ${ }^{3}$, Joyce Naiara da Silva ${ }^{4}$, Maria Luiza de Souza Medeiros ${ }^{4}$ \\ ${ }^{1}$ Universidade Federal da Paraíba, Centro de Ciências Agrárias, Programa de Pós-Graduação em Agronomia, CP \\ 58051-900, São Luís, MA, Brazil \\ ${ }^{2}$ Universidade Estadual do Maranhão, Centro de Ciências Agrárias, Programa de Pós-Graduação em Agroecologia, \\ CP 65.055-098, São Luís, MA, Brazil \\ ${ }^{3}$ Michigan State University, Department of Horticulture, East Lansing, MI 48824, United States \\ ${ }^{4}$ Universidade Federal da Paraíba-UFPB, Brazil
}

Corresponding author: pauloalexandrefernandes@outlook.com

\section{Abstract}

Luffa operculata (L.) is a native Brazilian biome plant used for the treatment of respiratory diseases. Although Brazil's flora comprises $67 \%$ of the world's plants, only $8 \%$ of Brazilian plant species are studied each year. The studies indicate that climate change in tropical biomes intensifies the increase in salinized areas by about $10 \%$ per year for several reasons, including high temperatures, low rainfall and high evapotranspiration rates, due to surface water scarcity. Therefore, the aim of the present study was to evaluate the germination behavior and vigor of $L$. operculata seeds submitted to saline stress at different temperatures. To simulate salt stress conditions, sodium chloride was applied at $0.0 ; 3.0 ; 6.0 ; 9.0$ and $12.0 \mathrm{dS} \mathrm{m}^{-1}$, at $25,30,35,20-30{ }^{\circ} \mathrm{C}$, with treatments distributed in a $5 \times 4$ factorial scheme (five levels of osmotic potential and four temperatures), using four replications. The seeds were then evaluated concerning water content, germination tests, first counts, germination speed index and seedling root and shoot lengths. At 30 and $35{ }^{\circ} \mathrm{C}$, the seed germination and vigor of $L$. operculata were less affected up to an osmotic potential of $9.0 \mathrm{dS} \mathrm{m}^{-1}$, where it is considered a moderate salinity tolerance. At $35 \stackrel{\circ}{\circ}$, the germination uniformity was reduced to 98 and $93 \%$ by applying the 6 and $9 \mathrm{dS} \mathrm{m}^{-1}$ solutions, respectively. For the same temperature, the germination velocity remained 6.09 (IVG) until the saline potential of $9.0 \mathrm{dS} \mathrm{m}^{-1}$.

Keywords: salinity, osmotic potential, environmental stress, seed vigor

Introduction

Luffa operculata L. Cogn., is a native Brazilian plant, albeit not endemic, found along the Gulf of California in Mexico, Panama, the coast of Venezuela, Ecuador and Peru. It has been recorded in the Brazilian Amazon, Caatinga, Cerrado, Mata Atlântica and Pantanal (Filipowicz et al., 2014). Studies estimate that $86 \%$ of informal plant traders recommend $L$. Operculata use among the most used herbal medicines in Brazil, especially for the treatment of bacterial infections, such as rhinitis and rhinosinusitis (Silva et al., 2018). Although relevant, and although the Brazilian flora comprises $67 \%$ of the world's plants, but only $8 \%$ of Brazilian plant species are studied each year (Lima et al., 2016).

In recent years, traditional herbal medicine has been practiced in several countries around the world, such as Germany, Canada, China, the United States, Spain and Russia, given that $25 \%$ of industrialized compounds are plant-derived (Palhares et al., 2015). Therefore, the Brazilian flora is of interest for international scientific communities concerning the research, conservation and rational use of these natural resources. However, environmental changes are occurring simultaneously worldwide, due to environmental pollution and global warming, which may induce rainfall regime changes and threaten the maintenance of plant genetic resources (Pereira et al., 2014; Pinto et al., 2018).

Studies indicate that climate change in tropical biomes intensifies the increase of salinized areas by about $10 \%$ annually for several reasons, including high temperatures, low rainfall and high evapotranspiration rates, due to surface water scarcity (Munns and Gilliham, 2015; Melo et al., 2017). It is estimated that $20 \%$ of the planet and more than $50 \%$ of arable land will be salinized by 2050 , including coastal plains, leading to brackish water, due to proximity to the sea (Shrivastava and Kumar, 2015; Santos et al., 2018). During a given period of the year, salinity situations, both for soil and water, may compromise seed germination and 
seedling establishment and survival (Martins et al., 2014; Zhang et al., 2019).

Temperature also significantly interferes with seed germination, especially when associated with salinity. The interaction of these factors affects speed and germination, due to influence on water absorption speed and biochemical reactions (Lin et al., 2018). Lower germination rates have been attributed to increased water evaporation at high temperatures, increasing salt concentration by capillary movement (Zhang et al., 2010). Therefore, the ability of certain species to germinate under water stress conditions confers ecological advantages over other species sensitive to saline stress-induced drought (Zhang et al., 2019).

One of the most widespread methods for the determination of plant tolerance to excess salts is the percentage of germination in saline substrates moistened with water (Zhang et al., 2012), as high intracellular $\mathrm{Na}^{+}$and $\mathrm{Cl}^{-}$ concentrations can inhibit embryonic cell metabolism during cell division and expansion. This, in turn, leads to delayed germination and may even result in seed death. In this method, the ability to germinate also indicates plant tolerance to salts in subsequent development stages (Lin et al., 2018).

The $L$. operculata germinative responses to environmental variables, particularly to salinity and temperature, have not been elucidated yet. The knowledge in this regard may subsidie management strategies for this species, mainly due to the importance of the plant for traditional medicine (Araújo et al., 2015). In addition, studies on the fibrous structure of the fruit of this species, which has been increasingly applied to energy converters and the immobilization of microbial cells in bioreactors are also paramount (Alves et al., 2018).

In view of the above, the aim of the present study was to evaluate the physiological potential of L. operculata seeds under the effect of different osmotic potentials induced by $\mathrm{NaCl}$ solutions and temperatures.

\section{Results and Discussion}

Seed water content ranged from 10 to $11 \%$ (values not shown) was considered uniform, since the maximum variation was of $1 \%$. Seed water content similarity was paramount to avoid physiological potential effects by metabolic activity differences due to seed water content differences (Araújo et al., 2015; Munns and Gilliham, 2015; Pereira et al., 2016).

The maximum percentage of germinated seedlings was verified on the fourth day after sowing at $35{ }^{\circ} \mathrm{C}$ and submitted to the control treatment of $0.0 \mathrm{dS} \mathrm{m}^{-1}$ in the first germination test (Figure 1). For this temperature, germination uniformity was reduced to 98 and $93 \%$, under 6 and $9 \mathrm{dS} \mathrm{m}^{-1}$ solutions, respectively. The osmotic potential required for maximum inhibition of the number of germinated $L$. operculata seedlings was $12 \mathrm{dS} \mathrm{m}^{-1}$. This is an additional indication of the moderate salinity tolerance of this species, suggesting that seed germination may occur under restricted soil moisture conditions.

Germination decreased at all assessed temperatures with increasing osmotic potential, and the highest germination percentages of 97,95 and $93 \%$ were obtained on a substrate moistened with deionized water $\left(0.0 \mathrm{dS} \mathrm{m}^{-1}\right)$ at 25,30 and 20-30 ㅇ, respectively (Figure 2 ). In addition, seed germination rates were higher than $80 \%$ even at high temperatures of 30 and $35 \stackrel{\circ}{\circ}$ until reaching an osmotic

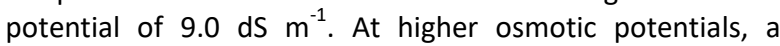
marked decrease in germination up to $12.0 \mathrm{dS} \mathrm{m}^{-1}$ was noted. After this point, germination was occurred only at 25 ${ }^{\circ} \mathrm{C}$.

Salinity affects seed germination through osmotic effects, ionic toxicity, or a combination of both. Therefore, seed water absorption restriction occurs due to the reduction of the potential gradient between the substrate and its surface, which is caused by the presence of salts, interfering with the water potential of the substrate (Pereira et al., 2016). However, salt tolerant species are referred because of having the ability to acquire a high osmotic potential. They allow the $\mathrm{NaCl}$ entry into the cells, using it as the osmolyte to maintain water absorption, which is essential for germination. In these plants, initial toxicity events during the osmotic phase of saline stress can be attenuated by the storage of the $\mathrm{Na}^{+}$and $\mathrm{Cl}^{-}$ions in cell vacuoles (Zhang et al., 2012).

The interaction between temperature and salinity during seed germination may, in part, be the result of sensitivity to high $\mathrm{Na}^{+}$content diluted in the substrate, whose toxicity may decrease enzymatic activity, such as $\alpha$-amylase and proteases and lipases responsible for reserve hydrolysis and consequently seed embryonic axis growth (Farooq et al., 2017). Similar studies carried out by Sohrabikertabad et al. (2013) on Cucumis melo L. seeds demonstrated that germination at $35 \stackrel{\circ}{\circ}$ was reduced from 91 to $7 \%$, when $\mathrm{NaCl}$ saline conditions increased to $13 \mathrm{dS} \mathrm{m}^{-1}$. For L. operculata, a reduction of 97 to $80 \%$ was observed at a $\mathrm{NaCl}$ concentration of $9 \mathrm{dS} \mathrm{m}^{-1}$, probably demonstrating the considerable tolerance of this species to the environmental salinity.

Studies have addressed $\mathrm{Na}^{+}$concentrations in seedlings stressed with $\mathrm{NaCl}$ as a tolerance measure (Sohrabikertabad et al., 2013; Ibrahim et al., 2016; Farooq et al., 2017; Jha et al., 2019). Therefore, little attention is given to the possible individual toxicity of excessive levels of $\mathrm{Cl}^{-}$ions to saline stress. However, substantial $\mathrm{Cl}^{-}$concentrations are often found in germinated seedling tissues on substrates moistened with saline solutions. High $\mathrm{Cl}^{-}$concentrations may be detrimental to cell integrity and may affect cell biochemistry through membrane damage or enzyme inhibition, especially if the vacuole can no longer sequester ions during seed imbibition (Teakle and Tyerman, 2010).

In plant cells, tolerance to salinity at high temperatures is due to plant response mechanisms, such as osmotic adjustment and antioxidant capacity, with salt toxicity attenuated by vacuolar compartmentalization (Farooq et al., 2017). Efficient salt tolerance responses at 35 oC where observed herein (Figures 1 and 2) concerning germination uniformity and percentages. This suggests that metabolic $L$. operculata seed tolerance to negative salinity effects may be related to osmotic adjustment mechanisms, such as the probable vacuolar compartmentalization of $\mathrm{Na}^{+}$and $\mathrm{Cl}^{-}$ions. Similar results were reported by Sohrabikertabad et al. (2013) after evaluating saline stress in C. melo seedlings germinated in $\mathrm{NaCl}$ at 35 ㅇ. .

Similar to the results of the first germination count and germination percentage, the germination speed index (IVG) of $L$. operculata seeds was affected by the increased osmotic potentials of the $\mathrm{NaCl}$ solutions, evidencing salinity effects 


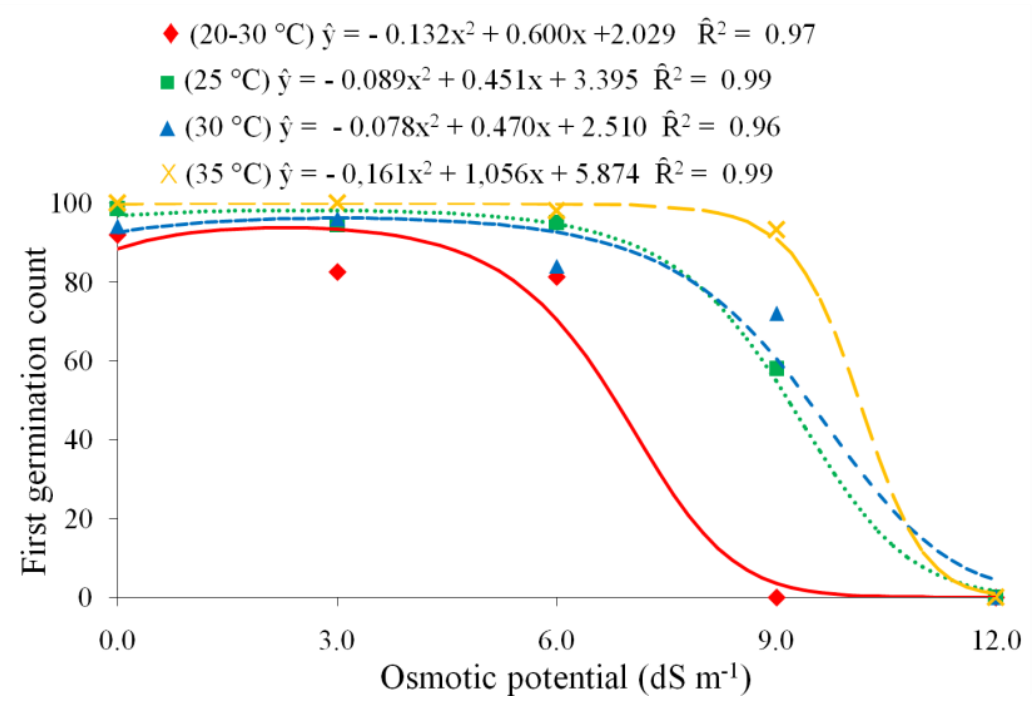

Figure 1. First germination count of Luffa operculata seeds subjected to different sodium chloride ( $\mathrm{NaCl}$ ) concentrations and temperatures.

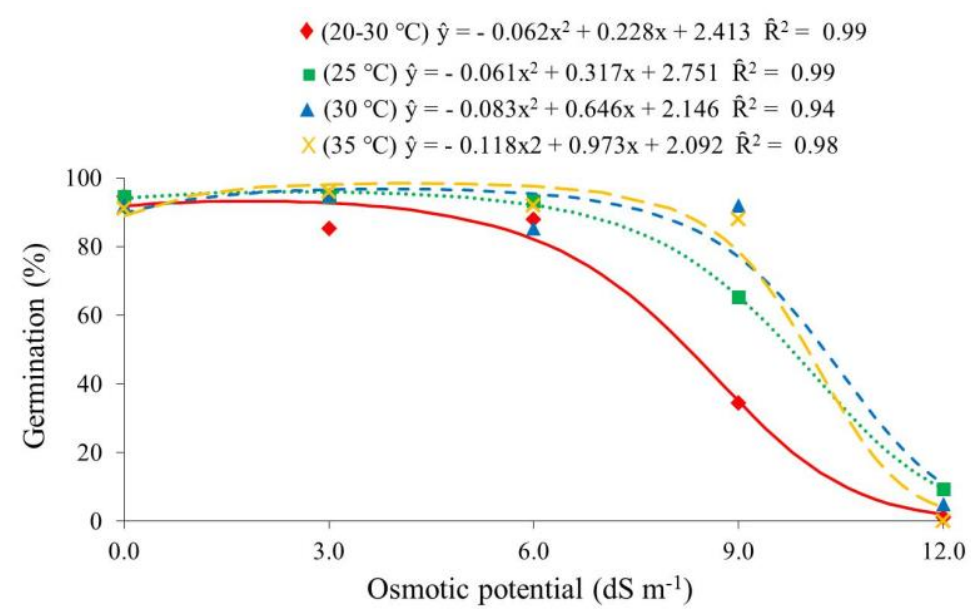

Figure 2. Germination (\%) of Luffa operculata seeds subjected to different sodium chloride (NaCl) concentrations and temperatures.

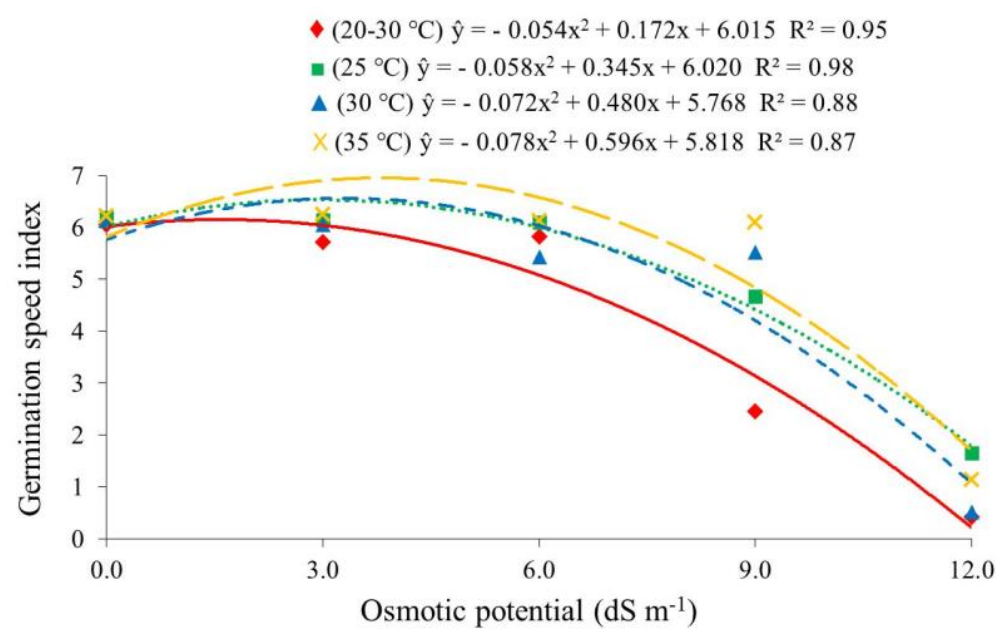

Figure 3. Germination speed index of Luffa operculata seeds subjected to different sodium chloride (NaCl) concentrations and temperatures. 


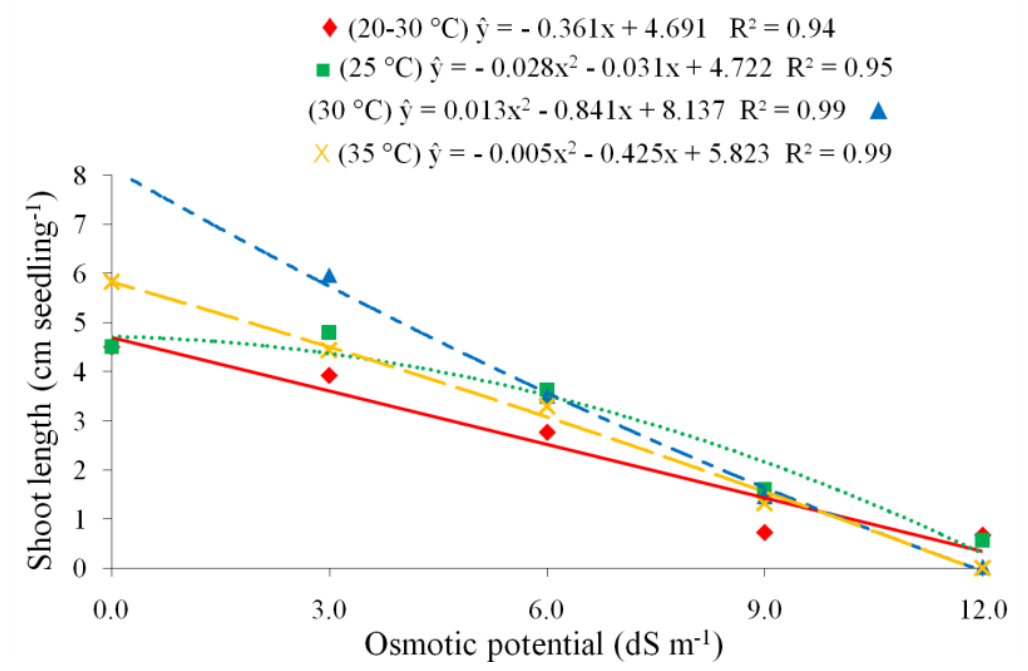

Figure 4. Shoot length of Luffa operculata seedlings originated from seeds subjected to different sodium chloride ( $\mathrm{NaCl)}$ concentrations and temperatures.

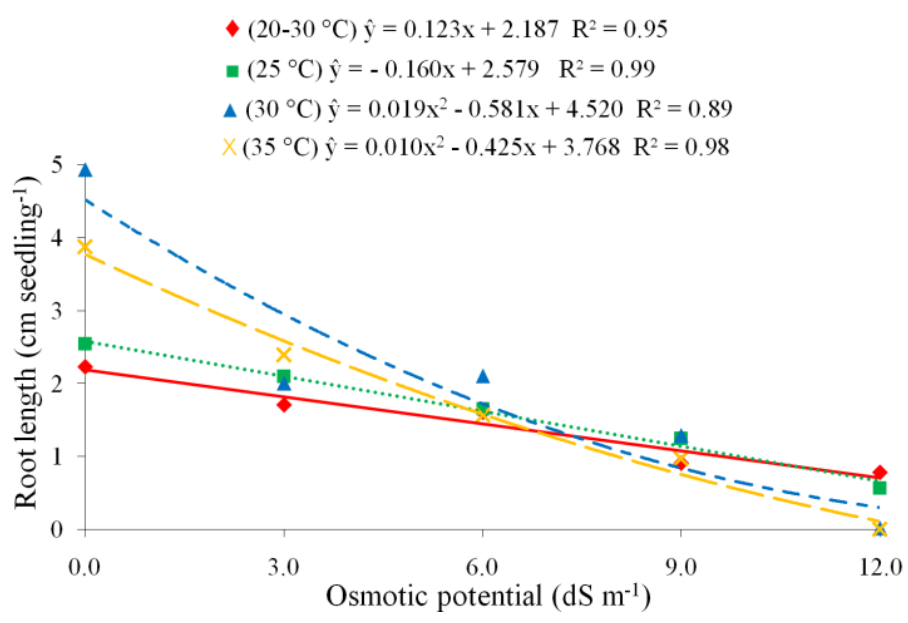

Figure 5. Root length of Luffa operculata seedlings originated from seeds subjected to different sodium chloride ( $\mathrm{NaCl)}$ concentrations and temperatures.

on germination delay. However, water potential was significant, as evaluated by interaction with temperature, with increasing minimum water availability for germination speed even at higher temperatures (Figure 3).

The higher IVGs of $6.96,6.57$ and 6.53 were observed in the absence of salinity $\left(0.0 \mathrm{dS} \mathrm{m}^{-1}\right)$ for seeds evaluated at 35,30 and $25 \stackrel{\circ}{\circ}$, respectively. In addition, significant reductions in IVG values where noted at increased saline concentrations, for all evaluated temperatures. However, decreases in germination speeds were less pronounced for seeds incubated at $35^{\circ} \mathrm{C}$, with IVG values maintained at about 6.09 up to a saline potential of $9.0 \mathrm{dS} \mathrm{m}^{-1}$ (Figure 3). These results support the hypothesis that $L$. operculata is tolerant to water stress induced by environmental salinization, mainly because germination speed is considered the first variable affected by decreased water availability (Zhang et al., 2010).
Usually, water stress, caused by salinity affects seeds, delaying water absorption and, consequently, the germination metabolism. Although environmental salinity inhibits germination, the harmful effect of salts is usually reduced at optimal temperatures (Marcos Filho, 2015), as observed in this study, where germination proceeded rapidly at thermal conditions between 25 to $35^{\circ} \mathrm{C}$. This may be due to the positive interaction between salinity and temperature, which may have attenuated negative osmolarity effects, partially mitigated at high saline concentrations (Figures 2 and 3 ).

The relationship between environmental factors, such as high temperatures and saline stress, strongly impairs seed germination, probably by accelerating respiration and metabolic events, intensifying toxic salt effects and deterioration (Zhang et al., 2012). However, plant cell toxicity can be attenuated by the action of tolerance 
mechanisms, allowing lower ionic cytoplasm concentrations and avoiding metabolic inhibition. Therefore, salinity tolerance may have ecophysiological implications (Farooq et al., 2017), as seeds capable of effectively responding to environmental changes and altering their germination physiology are more likely to survive and establish (Ibrahim et al., 2016; Jha et al., 2019). Regarding shoot and root lengths (Figures 4 and 5), L. operculata seedlings presented similar behavior to the IVG at each temperature, with decreasing values with increasing osmotic potentials. Seedlings submitted to germination at $30{ }^{\circ} \mathrm{C}$ and waterwetted substrate $\left(0.0 \mathrm{dS} \mathrm{m}^{-1}\right)$, reached the highest shoot and root length values, with means of 8.14 and $4.52 \mathrm{~cm} /$ seedling $^{-}$ 1 , respectively. On the other hand, increase in saline concentrations led to marked decreases of these length parameters at 30 and $35 \circ \mathrm{C}$ (Figures 4 and 5 ).

Saline stress can affect germination by inhibiting water uptake and/or $\mathrm{Na}^{+}$and $\mathrm{Cl}^{-}$ion accumulation. These negative effects can be attenuated by the ion binding to seed starch reserves. This mechanism acts in osmotic adjustment control by using organic solutes. Therefore, it probably requires an intensive energy demand, which can compromise seedling growth by leading to metabolic resource unavailability, i.e. sugars. Thus, it can be assumed that metabolic $\mathrm{NaCl}$ tolerance would be more important for seeds than other plant life cycle phases, due to their limited carbohydrate reserves (Flowers and Colmer, 2015). Another factor that affects seedling development at the end of the germination process occurs with radicle emission, the first part of the seed to emerge during germination. At this moment, the cellular protoplasm is exposed to excessive $\mathrm{Na}^{+}$and $\mathrm{Cl}^{-}$ concentrations diluted in the substrate water that surrounds the radicle zone, whose toxic effect favors the reduction of root and seedling elongation rates (Farooq et al., 2017). Studies on seed germination have reported that excess $\mathrm{Na}^{+}$ is often considered to be responsible for seedling growth reduction under salt conditions, while increasing intracellular $\mathrm{Cl}^{-}$concentrations can restrict cell division metabolism and expansion stages (Keshavarzi, 2011).

There is indirect evidence for some plant species that the ability to accumulate $\mathrm{Cl}^{-}$and $\mathrm{Na}^{+}$ions in the cytoplasm and cell wall cell vacuole is associated with salt tolerance. However, high concentrations of these ions in the plant cell wall may result in reduced turgor, resulting in atrophied seedlings (Hanin et al., 2016), which is probably the case of the present study. In addition, salinity can promote the accumulation of free amino acids, ammonium and nitrate within seedling cells, reducing the activities of enzymes involved in nitrogen assimilation, necessary for plant tissue formation. For example, in Curcubita pepo L., saline stress has been reported as suppressing the action of the enzyme $\mathrm{NADH}$-glutamate synthase and glutamine synthetase (Teakle and Tyerman, 2010; Zhang et al., 2019). The high salinity concentrations induced by $\mathrm{NaCl}$ also negatively affect seedling length in other cucurbitaceae, such as Cucumis anguria L. (Alves et al., 2014) and C. pepo (Harter et al., 2014). Guedes et al., (2011) assessed Chorisia glaziovii O. Kuntze seeds and observed that seedling length was less affected by salinity at 25 and $20-30{ }^{\circ} \mathrm{C}$, similar to the results obtained in the present study. Salinization is a stress factor for plants, as water is osmotically retained in saline solution. Increase of saline concentrations reduces water availability (Munns and Gilliham, 2015).

\section{Materials and Methods}

Fruits were collected from ten matrix $L$. operculata plants in the municipality of Areia - PB, Paraíba, Brazil $\left(06^{\circ} 57^{\prime} 46^{\prime \prime} \mathrm{S}\right.$ $\left.35^{\circ} 41^{\prime} 31^{\prime \prime} \mathrm{W}\right)$. The local climate is classified as hot tropical semi-arid, with an annual average rainfall of $838.1 \mathrm{~mm}$, concentrated from February to April, with an average temperature of 26 to 28 oC (Ipece, 2005).

The collected material was packed in polyethylene bags and taken to the Seed Analysis Laboratory belonging to the Agricultural Sciences Center of the Federal University of Paraíba, Brazil. The fruits were manually opened for seed removal. The seeds where then placed on paper towels to dry at room temperature ( $25 \pm 3 \circ \mathrm{o}$ ) for 24 hours. They were then homogenized and the following attributed and tests were performed.

\section{Water content}

Water content was determined by the greenhouse method, by maintaining the seeds at $105 \pm 3{ }^{\circ} \mathrm{C}$ for 24 hours. (Brasil, 2009), using four 25 -seed replicates.

\section{Osmotic potential assessments}

Saline stress was simulated using sodium chloride $(\mathrm{NaCl})$ as the solute at the following concentrations: $1.76,3.53,5.31$ and $7.08 \mathrm{~g} \mathrm{~L}^{-1}$, diluted in distilled and deionized water. The treatments constituted by osmotic potentials were confirmed by the electrical conductivity of the solutions: 3.0, $6.0,9.0$ and $12.0 \mathrm{dS} \mathrm{m}^{-1}$, using a digital conductivity meter. For the control treatment, distilled and deionized water was used to moisten the substrate.

The electrical conductivity values of the $\mathrm{NaCl}$ solutions were obtained using the following equation: $\left.C S=\frac{0.001(C E s-C E a n) P e q}{0.97}\right)$ proposed by Richards (1954), where; CS $=0.001$ (CEs - CEan) Peq/0.97, in which CS = concentration $\left(\mathrm{g} \mathrm{L}^{-1}\right)$; CEs = electrical conductivity of the water of the mixture at $25{ }^{\circ} \mathrm{C}\left(\mathrm{dS} \mathrm{m} \mathrm{m}^{-1}\right)$, CEan = electrical conductivity of the water ( $\left.\mathrm{dS} \mathrm{m}^{-1}\right)$, Peq = equivalent weight of the salt and $0.97=$ sodium estimated chloride purity percentage.

\section{Germination test}

Four batch of 50 -seed replicates were treated with the Captana ${ }^{\circledR}$ fungicide at a concentration of $240 \mathrm{~g} / 100 \mathrm{~kg}^{-1}$ of seeds. They were then distributed onto two Germitest ${ }^{\circledR}$ paper towels, covered with a third sheet and arranged as a roll. The substrate was moistened with distilled and deionized water or $\mathrm{NaCl}$ solutions, using an amount equivalent to 2.5 times the mass of the sheet prior to hydration. The rolls were placed in transparent $0.04 \mathrm{~mm}$ thick plastic bags to reduce water loss through evaporation. The treatments were evaluated by seed germination, conducted in chambers regulated at $25,30,35$ and 20-30 \pm 3 oC with a12-hour photoperiod. The evaluations were carried out by daily counting from the fourth to the eighth day after the beginning of the tests (Araujo et al., 2015), compared to normal seedling germination (Brasil, 2009). Data were expressed as percentages. 


\section{First germination count}

This test was conducted alongside the germination test, with normal seedling counts performed on the fourth day after the beginning of the test. Data were expressed as percentages.

\section{Speed germination index}

This test was conducted alongside the germination test, from the fourth to the eighth day after sowing, computing the number of germinated seedlings per day and applying the formula proposed by Maguire, (1962).

\section{Evaluation of seedling development}

This character was evaluated at the end of the germination test by measuring the length of seedling aerial portions and primary roots, using a centimeter-graduated ruler. The results were expressed as $\mathrm{cm} /$ seedling $^{-1}$ (Nakagawa, 1999). The experimental design was completely randomized, with treatments distributed in a $5 \times 4$ factorial scheme (five levels of osmotic potential and four temperatures), using four replications. The data were submitted to an analysis of variance and polynomial regression. The linear and quadratic models were tested, selecting the significant higher order model $\left(R^{2}\right)$. The variables referring to percentages and first germination counts were submitted to a binomial logistic analysis, using the SAS/STAT ${ }^{\circledR}$ software version 9.3 (Barbosa and Maldonado Júnior, 2015).

\section{Conclusions}

L. operculata seed germination and vigor at 30 and $35{ }^{\circ} \mathrm{C}$ were less affected up to an osmotic potential of $9.0 \mathrm{dS} \mathrm{m}^{-1}$, at which it developed a moderate tolerance to salinity. $L$. operculata tolerates up to $9.0 \mathrm{dS} \mathrm{m}^{-1}$, about $7.61 \mathrm{~g} \mathrm{~L}^{-1}$ of $\mathrm{NaCl}$ salinity, and is relatively tolerant to salt-induced water stress during germination and initial seedling growth stages. $L$. operculata seeds are more adapted to germinate under salt

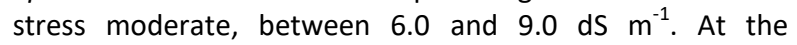
temperature of $35 \circ \mathrm{C}$, germination uniformity was reduced to 98 and $93 \%$, when applying the 6 and $9 \mathrm{dS} \mathrm{m}^{-1}$ solutions were applied, respectively. For the same temperature, the germination velocity (IVG) remained at about 6.09 until the saline potential of $9.0 \mathrm{dS} \mathrm{m}^{-1}$.

\section{References}

Alves CZ, Lourenço FMS, Silva JB, Silva TRB (2014) Efeito do estresse hídrico e salino na germinação e vigor de se mentes de maxixe. Interciencia. 39(5): 333-337.

Alves CDS, Frias HV, Kirsten TB, Cordeiro F, Bernardi, MM, Suffredini IB (2018) Luffa operculata fruit aqueous extract induces motor impairments, anxiety-like behavior, and testis damage in rats. J Ethnopharmacol. 222(2): 52-60.

Araújo PC, Alves EU, Araújo LR, Alves MM, Medeiros JGFM (2015) Tratamentos para superar a dormência de sementes de Luffa operculata (L.) Cogniaux. Rev Caatinga. 28(2): 76-83.

Barbosa JC, Maldonado-Júnior W (2015) Experimentação agronômica e agroestat. 1rd ed, FUNEP, Jaboticabal. 396.
BRASIL (2009) Ministério da agricultura, pecuária e abastecimento. Regras para análise de sementes. Secretária de defesa agropecuária. Brasília: MAPA/ACS. 395.

Farooq M, Nirmali GN, Hussain M, Barthakur S, Paul S, Bharadwaj N, Migdadi HM, Alghamdi SS, Siddique KHM (2017) Effects, tolerance mechanisms and management of salt stress in grain legumes. Plant Physiol Biochem. 118(4): 199-217.

Filipowicz N, Schaefer H, Renner SS (2014) Revisiting Luffa (Cucurbitaceae) 25 years after C. heiser: Species boundaries and application of names tested with plastid and nuclear DNA sequences. Syst Bot. 39(1): 205-215.

Flowers TF, Colmer TD (2015) Plant salt tolerance: adaptations in halophytes. Ann Bot. 115(3): 327-331.

Hanin M, Chantal EC, Ngom M, Laurent LL, Masmoudi K (2016) New insights on plant salt tolerance mechanisms and their potential use for breeding. Front Plant Sci. 7(123): 1787-1798.

Harter LSH, Harter FS, Deuner C, Meneghello GE, Villela FA (2014) Salinidade e desempenho fisiológico de sementes e plântulas de mogango. Hort Brasil. 32(1): 80-85.

Ibrahim EA (2016) Seed priming to alleviate salinity stress in germinating seeds. J Plant Physiol. 192(2): 38-46.

Jha UC, Bohra A, Jha R, Parida SK (2019) Salinity stress response and 'omics' approaches for improving salinity stress tolerance in major grain legumes. Plant Cell Rep. 38(3): 255-277.

Lin J, Hua X, Peng X, Dong B, Yan X (2018) Germination responses of ryegrass (annual vs. perennial) seed to the interactive effects of temperature and salt-alkali stress. Front Plant Sci. 1458(9): 1-10.

Maguire JD 1962. Speed of germination and in selection and evaluation for seedling emergence and vigor. Crop Sci. 2(1): 176-177.

Martins CC, Pereira, MRR. Lopes MTG (2014) Germination of eucalyptus seeds under water and salt stress. Biosci J. 30(3): 318-329.

Melo PAFR, Cavalcanti MI, Alves EU, Martins CC, Araujo LR (2017) Substrates and temperatures in the germination of Eriotheca gracilipes seeds. Rev Cienc Agron. 48(2): 303309.

Munns R, Gilliham M (2015) Salinity tolerance of crops what is the cost ?. New Phytol. 208(3): 668-73.

Pereira MRR, Martins CC, Martins D, Silva RJN (2014) Saline water stress and the germination of seeds of Raphanus raphanistrum and Senna obtusifolia. Biosc J. 30(3): 687696.

Nakagawa J (1999) Testes de vigor baseados no desempenho das plântulas. In: KRZYZANOSKI FC, VIEIRA RD, FRANÇA NETO JB (Ed.). Vigor de sementes: conceitos e testes. ed, ABRATES, Londrina. Cap. 2, 1-24.

Pereira FECB, Medeiros Filho S, Torres BS, Martins CC, Selma F, Brito SF (2016) Saline stress and temperatures on germination and vigor of Piptadenia moniliformis Benth. Seeds. Rev Bras Eng Agric. 20(7): 649-653.

Richards LA (1954) Diagnóstico y rehabilitacion de suelos salinos y sádicos. México: Departamento de agricultura de los Estados Unidos de América. 172. (manual de agricultura, 60).

Santos AA, Silveira JAG, Bonifacio A, Rodrigues AC, Figueiredo MVB (2018) Antioxidant response of cowpea 
co-inoculated with plant growth-promoting bacteria under salt stress. Braz J Microbiol. 49(3): 513-521.

Silva L, Costa HO, Souza CF, Lopes EMC, UEDA SMY (2018) Preclinical evaluation of Luffa operculata Cogn.and its main active principle in the treatment of bacterial rhinosinusitis. Braz J Otorhinolar. 84(1): 82-88.

Sohrabikertabad S, Ghanbari A, Mohamad HR, Mahalati MNI, Gherekhloo J (2013) Effect of desiccation and salinity stress on seed germination and initial plant growth of Cucumis melo. Planta Daninha. 31(4): 833-841.

Teakle NL, Tyerman SD (2010) Mechanisms of $\mathrm{Cl}^{-}$transport contributing to salt tolerance. Plant Cell Envir. 33(4): 566589.

Zhang W, Brandt M, Penuelas J, Guichard F, Tong X, Feng Tian F, Fensholt R (2019) Ecosystem structural changes controlled by altered rainfall climatology in tropical savannas. Nat Commun. 10(671): 1-7.

Zhang H, Irving LJY, Tianc Y, Zhoua D (2012) Influence of salinity and temperature on seed germination rate and the hydrotime model parameters for the halophyte, Chloris virgata, and the glycophyte, Digitaria sanguinalis. S Afr J Bot. 78(4): 203-210.

Zhang H, Irving LJ, Mcgill C, Matthew C, Zhou D, Kemp P (2010) The effects of salinity and osmotic stress on barley germination rate: sodium as an osmotic regulator. Ann Bot. 106(6): 1027-1035. 